\title{
2 Life-Cycle Assessment of timber frame constructions - 3 the case of rooftop extensions
}

4 Wijnants L.*, Allacker K., De Troyer F.

5 Department of Architecture, Faculty of Engineering Science, KU Leuven, Kasteelpark Arenberg 1, 3001

6 Leuven, Belgium

$7 \quad *$ Corresponding author: lien.wijnants@kuleuven.be, +3216329096

8 Abstract

9 Due to the growing population, the revived trend of living in urban areas and the scarcity of building plots, the

10 idea of vertically extending existing residential buildings is gaining popularity in Belgium. Timber frame

11 constructions are appropriate due to their light weight and lack of point loads. This article aims to assess (1)

12 the potential environmental impact reduction of light-weight timber frame constructions for rooftop extensions

13 by changing composition and dimensions and (2) the effect of biogenic carbon. Timber frame walls and roofs

14 are analyzed based on the life-cycle assessment method. Starting from the current building practice in

15 Flanders, various parameters are assessed. The effect of using I-joists instead of solid studs, of adjusting the

16 center-to-center distance between the studs and of changing materials for different layers is analyzed. The

17 results showed a limited environmental impact reduction of using I-joist instead of solid studs and of adjusting

18 the center-to-center distance. Changing the composition of the walls and roofs in terms of materials can lead to

19 a total life-cycle environmental reduction of $22 \%$ and $14 \%$, respectively. If biogenic carbon accounting is

20 integrated in the assessment method, based on the ILCD method, the total life-cycle environmental impact is

21 reduced by up to $35 \%$ and can lead to significant differences in the preferred choice of timber frame composition.

\section{Highlights}

- Influence of changing construction and material parameters is assessed using LCA

- Environmental impact can be reduced by up to $22 \%$ by changing wall parameters

- Environmental impact can be reduced by up to $14 \%$ by changing roof composition

- Accounting for biogenic carbon can lead to significant differences in preferred choice

\section{Keywords}

29 Environmental impact, densification, wood preservative, biogenic carbon, timber frame 
31 The construction sector faces an important challenge in order to meet the European objectives concerning

32 sustainability and energy consumption. These objectives require a $40 \%$ reduction of greenhouse gas (GHG)

33 emissions from 1990 levels by 2030 and achieving energy savings of at least $27 \%$ (General Secretariat of the

34 European Council, 2014). Buildings account for a major share (i.e. $36 \%$ of GHG emissions in the EU (Artola

35 et al., 2016)) and are therefore important in meeting these targets. Hence, improving the energy efficiency of

36 buildings has become a priority, although the GHG emissions during the production of materials should not be

37 ignored. In the past few decades, research has mainly focused on improving the energy performance of

38 buildings and on transforming existing buildings into passive or nearly zero energy buildings (Asadi et al.,

39 2012; Brown et al., 2013; Ma et al., 2012; Silva et al., 2013). The scope of some of these studies was enlarged

40 by including embedded energy and by following an energy-based life-cycle approach (Famuyibo et al., 2013).

41 Various studies investigated the proportion of embodied energy compared to total life-cycle energy (Ibn-

42 Mohammed et al., 2013; Stephan et al., 2013). For instance, (Stephan et al., 2013) analyzed a Belgian passive

43 house over a service life of 100 years and concluded that the embodied energy can represent up to $77 \%$ of the

44 total energy. Once the energy demand of a building has been reduced, the choice of materials and resulting

45 maintenance, repair and replacements becomes relatively more important. As a reduction of operational energy

46 use is often realized by an increase in insulation material, an optimum between both should be found in order

47 to reduce the depletion of natural resources and the total environmental impact of a building. Therefore,

48 efficient material use is an important issue as well as adequate assessment of a wide range of impact

categories. Recently more and more studies have focused on these issues and emphasize their importance (e.g.

50 Ingrao et al., 2016; Kovacic et al., 2018; Maxineasa et al., 2018). Furthermore, the benefits of using wood

51 products in buildings to reduce GHG emissions are increasingly being analyzed and questioned. Hafner and

52 Schäfer (2017) analyzed the GHG emissions of small residential buildings during product and end-of-life

53 (EOL) stage and reported a potential reduction of $35 \%$ to $56 \%$ in timber houses compared to mineral

54 buildings. Ximenes and Grant (2013) compared a base house design with a timber-optimized house design and

55 also reported significant GHG emission savings. However, the EOL hypothesis of wooden products (Häfliger

56 et al., 2017) as well as the inclusion of carbon storage in landfill (Ximenes and Grant, 2013) can lead to

57 significant differences in GHG outcomes.

58 Apart from the need to reduce the environmental impact of energy consumption and material use, compact

59 building design and the need for increased urban density are important challenges. Despite a high population

60 density in Flanders (i.e. approximately three times higher than the average European population density, 
61 (Eurostat, 2018a)), the density measured within the built-up area is about $25 \%$ lower compared to that of

62 Europe as a whole (Eurostat, 2018b, 2018c)(Eurostat, 2018b, 2018c). The continuously growing Flemish

63 population combined with the decreasing household size have highlighted the need for additional housing units

64 (Ryckewaert et al., 2011). Densification of the current built-up area offers a solution to address these housing

65 needs without further fragmentation of remaining valuable open space.

66 In this context, this paper investigates rooftop extensions on existing residential buildings and aims at gaining

67 insight in which parameters influence their life-cycle environmental impact. To avoid overloading of the existing building structure and foundations, the focus is limited to light-weight timber rooftop extensions. As mentioned before, in addition to various studies indicating that wood mainly has advantages in terms of GWP compared to other materials, some studies produced a detailed environmental impact assessment of timber frame structures. (Achenbach et al., 2018) assessed the environmental impact of the production and construction stage of prefabricated timber houses and concluded that it is highly recommended to choose a house manufacturer located close to the construction site to limit the environmental impact related to the transport to the construction site. Maxineasa et al. (2018) assessed timber structures in pitched roofs considering a comprehensive set of impact categories. These are less of interest here as the rooftop extensions discussed in this paper have a flat roof. To date, information about the influence of material and dimension choices in timber frame walls and flat roofs is lacking. Therefore, we investigated the contribution of the various materials of a semi-prefabricated timber frame rooftop extension to the life-cycle environmental impact of materials used in a previous study (Wijnants et al., 2016). In this study, the wood-based work sections were identified as the ones with the largest environmental reduction potential. This paper therefore investigates the wood studs in the frames in more detail, both in terms of type of studs, dimensions and spacing. This is combined with an assessment of various insulation materials and thicknesses as insulation material is often placed between the studs. Furthermore, the influence of considering biogenic carbon sequestered in the timber-based materials on the overall environmental impact is discussed.

\section{2. Materials and methods}

\section{$86 \quad 2.1$ Goal and scope definition}

\section{$87 \quad$ 2.1.1 System boundaries and functional unit}

88 The goal of the study is to assess the life-cycle environmental impact of timber frame walls and roofs and to

89 gain insight in the various parameters to reduce the impact of these elements. The assessment considers the 
and construction), use stage (maintenance, repair and energy transmission losses) and EOL stage (demolition, transport to and EOL treatment). Benefits and loads resulting from reuse, energy recovery and recycling at the EOL are not considered. The system boundaries and input and output flows are shown in Figure 1. A detailed description of all life-cycle stages is provided in the subsequent paragraphs. The functional unit is defined as one square meter of a building element (i.e. $1 \mathrm{~m}^{2}$ wall or $1 \mathrm{~m}^{2}$ roof), assuming a building service life of 60 years with an average indoor air temperature of $18^{\circ} \mathrm{C}$, in the Belgian climate. This is in line with the rules defined in the Belgian LCA method for building elements as described in section 2.3 (Allacker et al., 2013).

INPUT FLOWS

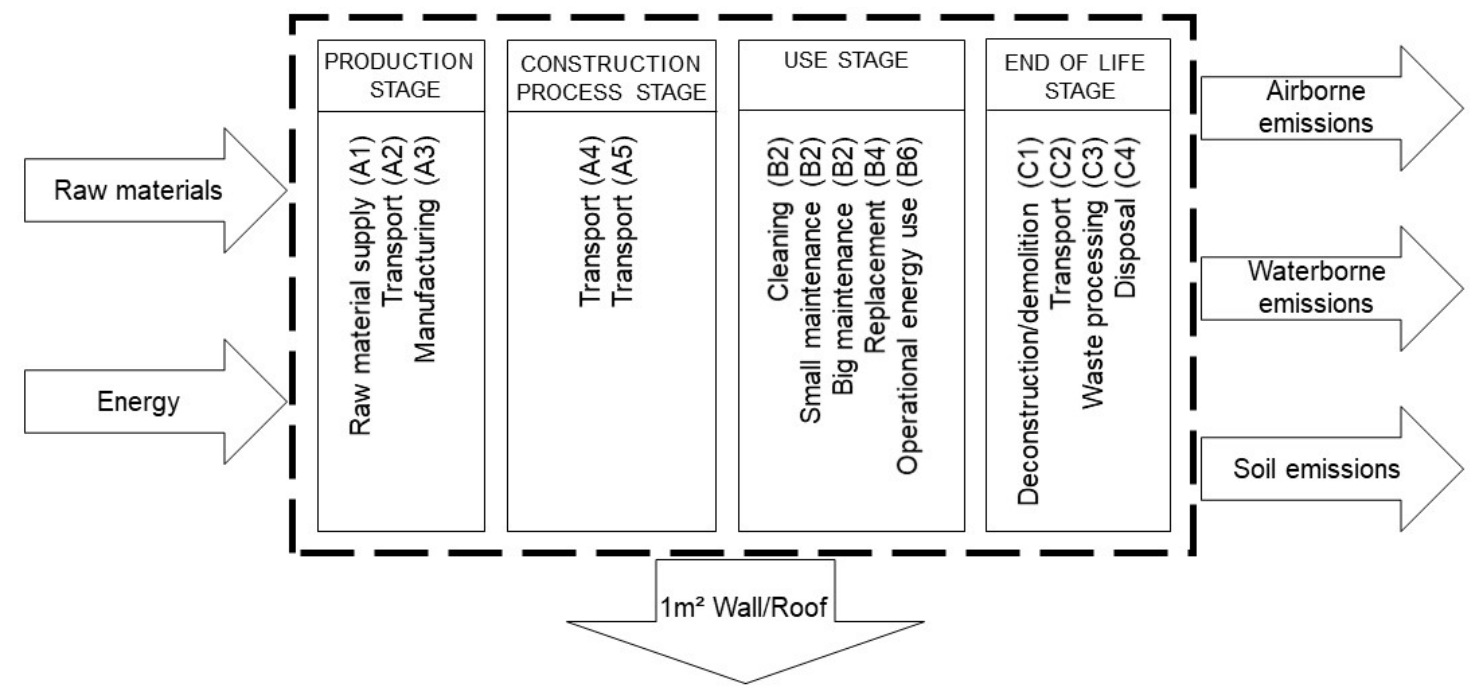

Figure 1 System boundaries (the various modules (A1 - C4) refer to the EN15804 modules).

Various timber frame walls with different stud types and dimensions were compared to assess the potential environmental impact reduction by changing the bearing structure. The composition of the timber frame wall elements is provided in Figure 2. The internal and external finishes were assumed identical in all cases, consisting of an OSB-board and a painted gypsum board on the inside and a bituminous wood fiber board and untreated wooden claddings on the outside. Solid wooden studs were compared with I-joists consisting of laminated veneer lumber flanges and an OSB web with a thickness of $10 \mathrm{~mm}$. The dimensions of the solid studs were based on commonly used timber frame sections in Belgium. The dimensions of the I-joists were based on the dimensions available on the market and were kept as closely as possible to the dimensions of the solid studs to allow for a meaningful comparison between both. A center-to-center distance of $40 \mathrm{~cm}$ was considered. The smallest dimension of the solid studs was $14.5 \mathrm{~cm}$. Because a wall with solid studs of $14.5 \mathrm{~cm}$ and insulation only between the studs does not fulfil current Energy Performance (EPB) requirements in Belgium, an additional insulation layer was provided on the outside. An insulating wood fiber board with a 
112 thickness of $18 \mathrm{~mm}$ (S14.5 (WfB)) or a $60 \mathrm{~mm}$ XPS board and a damp open foil (S14.5 (XPS)) was added to

113 this wall structure. Although a wall of I-joists with $16 \mathrm{~cm}$ insulation meets current EPB requirements, an extra

114 insulation layer in wood fiber (I16 (WfB)) or XPS (I16 (XPS)) was added in order to compare the

115

environmental impact difference of a thinner I-joist with an extra insulation layer and a thicker I-joist (I24). An

116 overview of the various dimensions of the studs analyzed, together with the R-value of the walls is provided in

117 Table 1. Detailed information of the wall composition is provided in the supplementary material (Table S1).
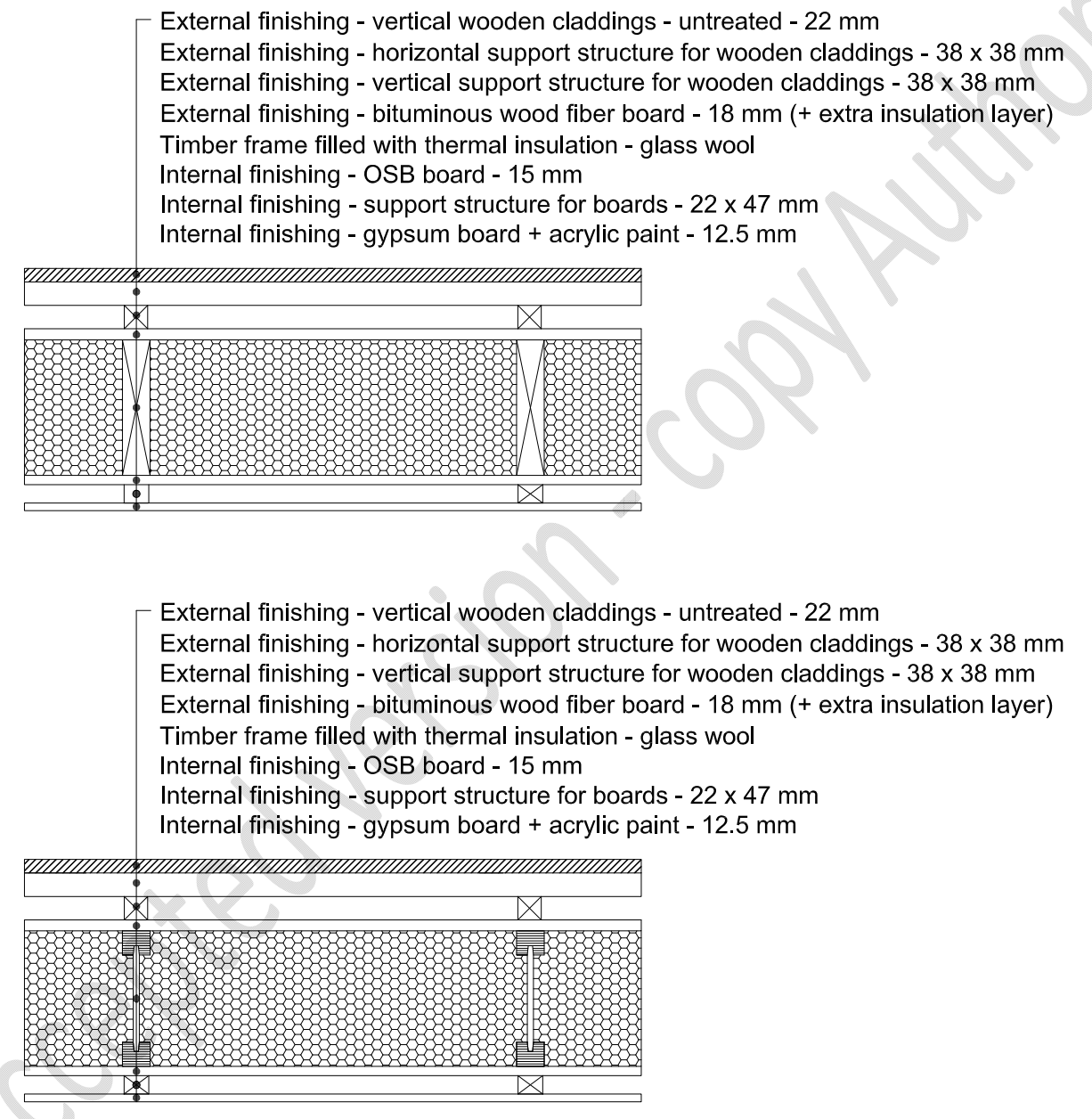

119 Figure 2 Wall composition with solid studs (above) and wall composition with I-joists (below). 
120 Table 1 Overview of the timber frame compositions and R-value of the walls.

\begin{tabular}{|l|c|c|c|c|c|c|}
\hline Name variant & $\begin{array}{c}\text { Type of } \\
\text { frame }\end{array}$ & $\begin{array}{c}\text { Thickness } \\
\text { frame }(\mathrm{cm})\end{array}$ & $\begin{array}{c}\text { c.t.c distance } \\
(\mathrm{cm})\end{array}$ & $\begin{array}{c}\text { Extra } \\
\text { insulation }\end{array}$ & $\begin{array}{c}\text { Total } \\
\text { thickness } \\
(\mathrm{cm})\end{array}$ & $\begin{array}{c}\text { R-value } \\
\left(\mathrm{m}^{2} \mathrm{~K} / \mathrm{W}\right)\end{array}$ \\
\hline S14.5 (WfB) - c.t.c. 40 & Solid studs & 14.5 & 40 & $2.2 \mathrm{~cm} \mathrm{WfB}$ & 33.25 & 4.55 \\
\hline S14.5 (XPS) - c.t.c. 40 & Solid studs & 14.5 & 40 & $6 \mathrm{~cm} \mathrm{XPS}$ & 37.05 & 5.87 \\
\hline S19.5 - c.t.c. 40 & Solid studs & 19.5 & 40 & $/$ & 36.05 & 4.91 \\
\hline S24.5 - c.t.c. 40 & Solid studs & 24.5 & 40 & $/$ & 41.05 & 5.95 \\
\hline I16 - c.t.c. 40 & I-joists & 16 & 40 & $/$ & 32.55 & 5.17 \\
\hline I16 (WfB) - c.t.c. 40 & I-joists & 16 & 40 & $8 \mathrm{~cm}$ WfB & 40.55 & 7.28 \\
\hline I16 (XPS) - c.t.c. 40 & I-joists & 16 & 40 & $6 \mathrm{~cm}$ XPS & 38.55 & 7.17 \\
\hline I20 - c.t.c. 40 & I-joists & 20 & 40 & $/$ & 36.55 & 6.33 \\
\hline I24 - c.t.c. 40 & I-joists & 24 & 40 & $/$ & 40.55 & 7.48 \\
\hline
\end{tabular}

$121 *$ Note: $\mathrm{S}=$ studs and I = I-joists, the numbers after the letters refer to the thickness.

122 Similar to the timber frame walls analysis, timber frame roof variants were analyzed to assess the potential

123 environmental impact reduction by changing the composition. Because similar conclusions regarding the

124 bearing structure were expected for the roof, the bearing structure was assumed to be identical in all cases.

125 Only insulation type and thickness differed amongst the roof alternatives as shown in Figure 3, Table 2 and

126 Table S2. The first two roofs had no insulation in between the I-joists but an insulation layer on top of $14 \mathrm{~cm}$

127 in PIR and $18 \mathrm{~cm}$ in PUR, respectively. The last two roof variants had insulation in between the studs as well

128 as insulation on top. In the 'stone wool 12 - PUR 20' roof, the space between the I-joists was partially filled

129 with stone wool and an extra layer of $20 \mathrm{~cm}$ PUR was added on top. The 'cellulose 30 - PIR 10' roof was

130 completely filled with cellulose and had an extra insulation layer of $10 \mathrm{~cm}$ PIR.

131

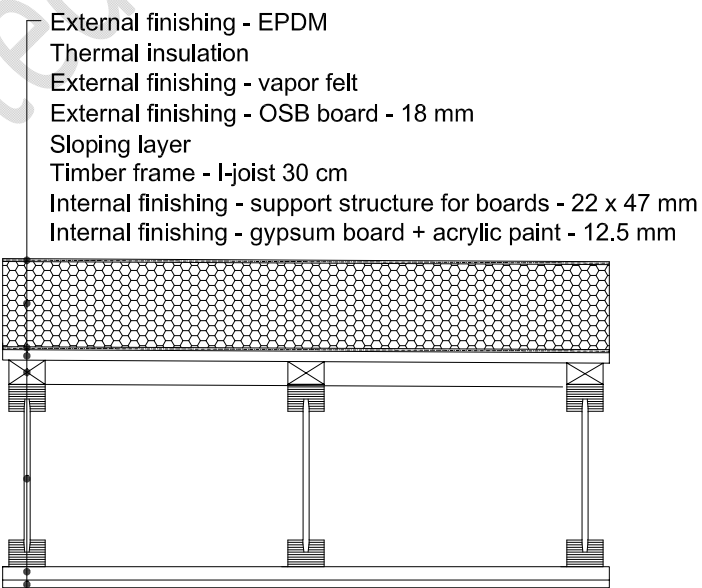




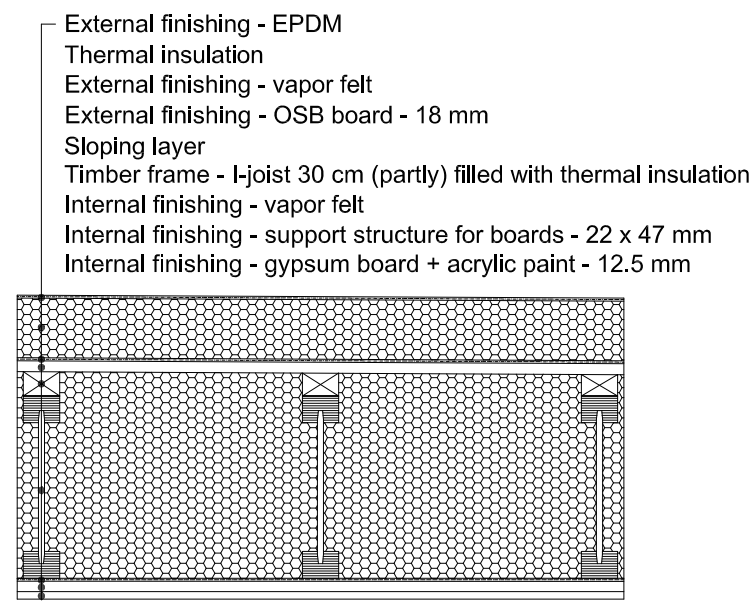

133 Figure 3 Roof composition with insulation on top (above) and roof composition with insulation between the 134 frame combined with insulation on top (below).

135 Table 2 Overview of the roof compositions and R-value of the roofs.

\begin{tabular}{|l|c|c|c|c|c|c|}
\hline Name variant & $\begin{array}{c}\text { Thickness I- } \\
\text { joists }(\mathrm{cm})\end{array}$ & $\begin{array}{c}\text { c.t.c distance } \\
(\mathrm{cm})\end{array}$ & $\begin{array}{c}\text { Insulation } \\
\text { between } \\
\text { frame }\end{array}$ & $\begin{array}{c}\text { Insulation } \\
\text { on top }\end{array}$ & $\begin{array}{c}\text { Total } \\
\text { thickness } \\
(\mathrm{cm})\end{array}$ & $\begin{array}{c}\text { R-value } \\
\left(\mathrm{m}^{2} \mathrm{~K} / \mathrm{W}\right)\end{array}$ \\
\hline PIR 14 & 30 & 40 & $/$ & $14 \mathrm{~cm}$ PIR & 49 & 6.09 \\
\hline PUR 18 & 30 & 40 & $/$ & $18 \mathrm{~cm}$ PUR & 53 & 7.62 \\
\hline stone wool 12 - PUR 20 & 30 & 40 & $\begin{array}{c}12 \mathrm{~cm} \text { stone } \\
\text { wool }\end{array}$ & $20 \mathrm{~cm}$ PUR & 55 & 10.35 \\
\hline cellulose 30 - PIR 10 & 30 & 40 & $\begin{array}{c}30 \mathrm{~cm} \\
\text { cellulose }\end{array}$ & $10 \mathrm{~cm}$ PIR & 45 & 11.71 \\
\hline
\end{tabular}

\subsection{Life-Cycle Inventory Analysis}

\section{$138 \quad$ 2.2.1 Production stage}

139 The Life-Cycle Inventory (LCI) data for production (cradle-to-gate) covers the extraction of raw materials,

140 transport of these materials to the manufacturer and the manufacturing process. Data were based on the

141 database Ecoinvent v3.2 (Ecoinvent, 2014). Data representative of Europe were selected, i.e. the construction

142 materials were assumed to be produced all over Europe. The Ecoinvent datasets used and the amounts of

143 materials included in the functional unit are included as supplementary information (Table S3-S7). An

144 important issue in the evaluation of timber-based construction materials is the wood preservation method.

145 Variations in humidity, temperature and climate are the primary factors affecting the risk of wood degradation.

146 (NBN EN 335, 2013) Depending on the type and duration of exposure to these factors and the possibility of

147 the construction drying during the life time of the timber, five use classes are distinguished. Construction wood

148 is classified in use class two. The wood in this use class is 'wood not in contact with soil' and 'normally not 
This means that insects and moisture are possible threats and wood preservation is often necessary. Currently, there are no mandatary Belgian standards regarding wood preservation in the private sector, but technical specifications have been outlined after a broad consultation of a wide range of major actors in the sector and are considered as "good practice" to be followed by architects and contractors. These technical specifications were published in STS 04.03 (Federale overheidsdienst economie, K.M.O., middenstand en energie, 2009). Wood preservation based on an immersion process 'A2.1/T3: behandeling door lange drenking' is currently the most commonly used one for timber frame constructions in Belgium (Dobbels, 2016; Federale overheidsdienst economie, K.M.O., middenstand en energie, 2009). This treatment involves submerging of wood into a dipping tank filled with wood preservative for a period of at least one hour (Federale overheidsdienst economie, K.M.O., middenstand en energie, 2009). An organic solvent-based wood preservative in accordance with A2.1 processes was modelled (Wijnants et al., 2017). The environmental impact due to the production of this organic solvent-based wood preservative was modelled based on the Ecoinvent record 'Wood preservation, dipping/immersion method, organic solvent based, indoor use, occasionally wet $\{R E R\} \mid$ wood preservation, dipping/immersion, solvent-based preservative, indoor use, occasionally wet | Alloc Rec, $U^{\prime}$. The wood preservative inventoried in this dataset is an organic solvent-based primer for use class two and contains $0.55 \%$ Iodopropynyl Butyl Carbamate (IPBC), $0.15 \%$ Permethrine and $0.6 \%$ Tebuconazole as active agents and a $100 \% \mathrm{v} / \mathrm{v}$ concentration for application. This record was adapted according to the composition of the Belgian wood preservative AXIL MULTI (Technische Goedkeuring ATG met Certificatie - Procédés voor de preventieve behandeling van het hout - ATG 12/2294 -AXIL MULTI, 2013). The quantity of active agents of this wood preservative were : $0.17 \%$ Propiconazole, $0.3 \%$ Tebuconazole, $0.1 \%$ Cypermethrine and $0.3 \%$ IPBC. As Propiconozale was not available in the Ecoinvent database, Tebuconazole was used as proxy because both are triazole fungicides (The American Phytopathological Society, 2017). Both the quantities of active agents and solvents were adapted in the

173 Ecoinvent dataset in line with the Belgian technical specifications. The record used covers the impregnation of wood in open tank and considered that the wood preservative penetrated the wood three millimeters with a critical concentrate value of $40 \mathrm{~kg} / \mathrm{m}^{3}$ in the treated zone. Hence, the amount of wood preservative in $1 \mathrm{~m}^{2}$ timber frame wall depended on the dimensions of the timber components (Table S3 and S7).

\section{$177 \quad$ 2.2.2 Transportation to the construction site and construction stage}


178 The transportation of building materials from the factory to the construction site depend on the location of the

179 construction site and the factory delivering the products. For the distances and transport means, average scenarios were assumed, as defined in the Belgian LCA method for building elements (Allacker et al., 2013).

Due to lack of data, the transportation and energy use of construction equipment was excluded from the assessment. However, these factors were expected to have a minor impact. Overall material loss during the construction stage was estimated to be $5 \%$. The environmental impact due to these losses relates to the necessary material production, transportation and EOL processes. The inventory of this life-cycle stage is included in the supplementary information (Table S8).

\subsubsection{Use stage}

The use stage covers the maintenance, replacement and energy use for heating by means of transmission losses during the building's service life. The wooden cladding is replaced every 20 years, the internal gypsum board every 30 years and the paint every 10 years. A big maintenance occurs every 10 years for the wooden cladding and gypsum boards and every 5 years for the paint. $10 \%$ of the material is replaced during the big maintenance. The operational energy use was estimated based on the Equivalent Degree Days (EDD) method. This method follows a static approach (Diensten voor de programmatie van het wetenschapsbeleid, 1984) and an average of 1200 equivalent degree days was determined as an appropriate value for well-insulated residential buildings in Belgium (Allacker, 2010). This value takes into account the average "free heating" by sun, people, lighting and equipment. The operational energy use at the building element level for heating due to transmission losses was calculated based on the following formula:

Yearly environmental impact $=\mathrm{U}_{\mathrm{EL}} \times \mathrm{A}_{\mathrm{EL}} \times \mathrm{DD}_{\mathrm{eq}} \div \eta_{\text {system }} \times \mathrm{EI}_{\text {heating }}$

With:

- $\mathrm{U}_{\mathrm{EL}}=$ the $\mathrm{U}$-value of the element $\left(\mathrm{W} / \mathrm{m}^{2} \mathrm{~K}\right)=1 / \mathrm{R}$-value;

- $\mathrm{A}_{\mathrm{EL}}=$ the surface area of the element $\left(\mathrm{m}^{2}\right)$;

- $\quad \mathrm{DD}_{\mathrm{eq}}=1200$ equivalent degree-days (Allacker 2010) multiplied with $\left((24 * 60 * 60) / 10^{6}\right)$ to convert days into seconds and joules into mega joules;

- $\quad \eta_{\mathrm{system}}=\mathrm{a}$ condensing gas boiler was considered as energy source for heating with an overall system efficiency of $87.4 \%$;

- $\quad \mathrm{EI}_{\text {heating }}=$ the environmental impact of heating produced by a condensing gas boiler.

An overview of the energy use for each of the building element options over a service life of 60 years is included in the supplementary information (Table S9). 
209 The impact of demolition, waste transport, waste processing and disposal is included in the EOL stage. In this 210 study, the EOL scenarios as defined in the Belgian LCA method for building elements (Allacker et al., 2013)

211 were assumed. These are summarized in Table 4. In the EOL scenario for timber waste, $5 \%$ of the treated 212 wood was considered as landfilled and $95 \%$ as incinerated without heat recovery. It was assumed that the

213 EOL processes will occur in Belgium. The energy mixes in the Ecoinvent EOL datasets were therefore 214 replaced by their Belgian equivalent. Due to a lack of EOL processes in Ecoinvent for wood treated with preservatives, an estimation of the environmental impact due to incineration was made based on available data in literature. For the EOL incineration of organic-solvent-based treated wood, the emissions to air were based on available data in literature (Salthammer et al., 1995; Tame et al., 2007) and calculated based on the constituents of the wood preservative as described in Section 2.2.1. The Ecoinvent dataset of untreated wood was used as proxy for landfilling. The EOL processes for incineration of laminated timber, oriented strand board (OSB) and wood fiber are currently lacking in the Ecoinvent database. An estimation of their environmental impact was based on the required amount of glue during production and on available data in literature (Moreno et al., 2017; Risholm-Sundman and Vestin, 2005).

\section{$223 \quad 2.3$ Life-cycle impact assessment}

224 For the life-cycle environmental impact assessment, the Belgian LCA method for building elements, i.e. the 225 MMG ("Environmental profile of building elements") method (Allacker et al., 2013) was used. The MMG 226 method follows an integrated life cycle approach, as recommended by the European standards EN 15804+A1 227 (CEN, 2013) and EN 15978 (CEN, 2011) for the evaluation of construction products and buildings. The MMG method includes two sets of impact categories: (1) the ones defined by the above-mentioned CEN TC 350 standards and (2) seven additional impact categories, referred to as CEN+ indicators (Table 3). The latter were added at the request of Belgian policy-makers and based on the International Reference Life Cycle Data

231 System (ILCD) Handbook (IES, 2010).

232 Table 3 Overview of the CEN and CEN+ impact categories. (Allacker et al., 2013)

\begin{tabular}{ll}
\hline CEN indicators & CEN+ indicators \\
\hline Global warming & Human toxicity, cancer and non-cancer effects \\
Depletion of the stratospheric ozone layer & Particulate matter formation \\
Acidification for soil and water & Ionising radiation: human health/ecosystems \\
Eutrophication freshwater and marine & Ecotoxicity: freshwater \\
Photochemical oxidant formation & Land occupation: soil organic matter
\end{tabular}


Abiotic depletion of non-fossil resources

Abiotic depletion of fossil resources
Land occupation: agricultural/forest and urban

Land transformation: soil organic matter

Land transformation: tropical rain forest

Water scarcity

Besides the characterized values, the method includes a way to calculate a single aggregated score expressed in monetary values (EUR), indicating the external environmental cost, which expresses the environmental damage that is passed on to society. The monetization values are based on damage and/or prevention costs as described in (De Nocker and Debacker, 2015) and the MMG central values for Western-Europe were used

(Table S10 and S11 in the supplementary material). In contradiction to the MMG LCA method, no discounting of future environmental costs was applied, i.e. future environmental costs were accounted for as present environmental costs.

\subsection{Carbon sequestration, temporary storage in bio-based products and delayed emissions}

An intrinsic characteristic of bio-based construction materials is their ability of capturing biogenic $\mathrm{CO}_{2}$ during growth and of (temporarily) storing carbon during their life cycle. In many LCA studies, it is assumed that the biological uptake during growth and release in the EOL stage cancel each other out. Thus the amount of biogenic carbon sequestered is considered equal to the amount of biogenic carbon emitted at the EOL stage. In some studies, a credit is given to temporary carbon dioxide storage by discounting delayed emissions. These calculations are restricted to the 100-year assessment period and imply that the later an emission occurs, the lower its impact will be. The widely spread specifications of PAS 2050 and the ILCD handbook propose an accounting method without considering the timing of sequestration. A credit for delayed emissions can optionally be added. However, these standard calculation methods are often criticized and some researchers proposed alternative methods (e.g. Brandão et al., 2013; Levasseur et al., 2013; Vogtländer et al., 2014). For instance, a dynamic LCA approach was proposed by Levasseur et al. (2013) to allow for a consistent assessment of emission flows and radiative effects over time. According to Vogtländer et al. (2014), the application of wood in construction will not always lead to extra carbon sequestration, as this is determined by the origin of the wood and the growth of the wood markets. Vogtländer et al. therefore propose a calculation method based on the global carbon cycle and a land-use change. Furthermore, there is no consensus on whether delayed emissions have a positive or negative effect on the environment because the temporarily stored biogenic $\mathrm{CO}_{2}$ will exert its full radiative forcing effect later on when it is re-emitted into the atmosphere. Although a lot of research has been performed in the past few years, there is currently no overall consensus on whether the possible benefits of biogenic carbon sequestration, temporary storage and delayed 
emission should be accounted for, nor on which method should be used. Recent studies, however, showed that methodological choices in accounting carbon sequestration greatly influence results (Garcia and Freire, 2014;

262 Vogtländer et al., 2014). Given considerable uncertainty on these matters and lacking consensus regarding the calculation method, the method described in the ILCD handbook was used in the basic reporting in this study

264 for the biogenic $\mathrm{CO}_{2}$ flows. A credit for temporary storage/delayed emissions of fossil $\mathrm{CO}_{2}$ was added as specified in the ILCD handbook in order to have a consistent modelling of the biogenic and fossil $\mathrm{CO}_{2}$. The results are shown separately, as recommended by several researchers, and must be interpreted with the abovementioned remarks in mind. A schematic representation of the life cycle of biogenic carbon is shown in Figure 4. The biogenic $\mathrm{CO}_{2}$ uptake for structural wood and wood-based products was calculated based on dry wood weight and on an average carbon content of $50 \%$ (Aalde et al., 2006; NBN EN 16449, 2014). It was assumed that all timber originates from sustainably managed forests, although the timing of carbon uptake during the trees' growth was not considered. It was assumed as sequestered at the moment of manufacturing the building product. For the share of biogenic $\mathrm{CO}_{2}$ that is re-emitted at the EOL, a correction flow for delayed emission of biogenic carbon dioxide was measured in flow property "Mass*years" and reference unit "kg*a" to carry a GWP 100 impact factor of "- $-0.01 \mathrm{~kg} \mathrm{CO}_{2}$ equivalent" per $\mathrm{kg} * \mathrm{a}$, as described in the ILCD handbook (IES, 2010), indicated in the figures as 'biogenic carbon temporarily stored'. By including accounting for temporary storage, it was thus assumed that near-term radiative forcing is more relevant than future radiative forcing. As described above, part of the treated wood is landfilled and part of the wood is incinerated. Not all sequestered biogenic $\mathrm{CO}_{2}$ will be released at the moment of landfill (Micales and Skog, 1997; Wang et al., 2011; Ximenes et al., 2008). Micales and Skog (1997) estimated that only 0\%-3\% of the carbon content of wood is ever emitted as landfill gas, with a maximum of $1.9 \%$ released as methane and $1.3 \%$ released as carbon dioxide. Other studies (Wang et al., 2013, 2011; Ximenes et al., 2008) also indicated no significant degradation of various woods during landfill. Losses between $0 \%$ and $19.9 \%$ are reported (further referred to as carbon conversion factor), depending on the type of wood product analyzed (e.g. hard wood, soft wood, particle board,..). In this study, a carbon conversion factor between $1.3 \%$ and $19.9 \%$ was assumed depending on the wood type and considered $50 \%$ released as $\mathrm{CO}_{2}$ and $50 \%$ as $\mathrm{CH}_{4}$. It was assumed that the release of both start when the wood is landfilled and that the total amount of carbon dioxide and methane emitted is equally spread over a period of 20 years after landfilling. Moreover, no methane was assumed collected in landfill gas collection and/or burned in combustion systems or oxidized in the surface layer of the landfill. The assumptions made in the EOL calculations are summarized in Table 4. For cellulose insulation, the uptake of 
292 at EOL was included in the calculations.

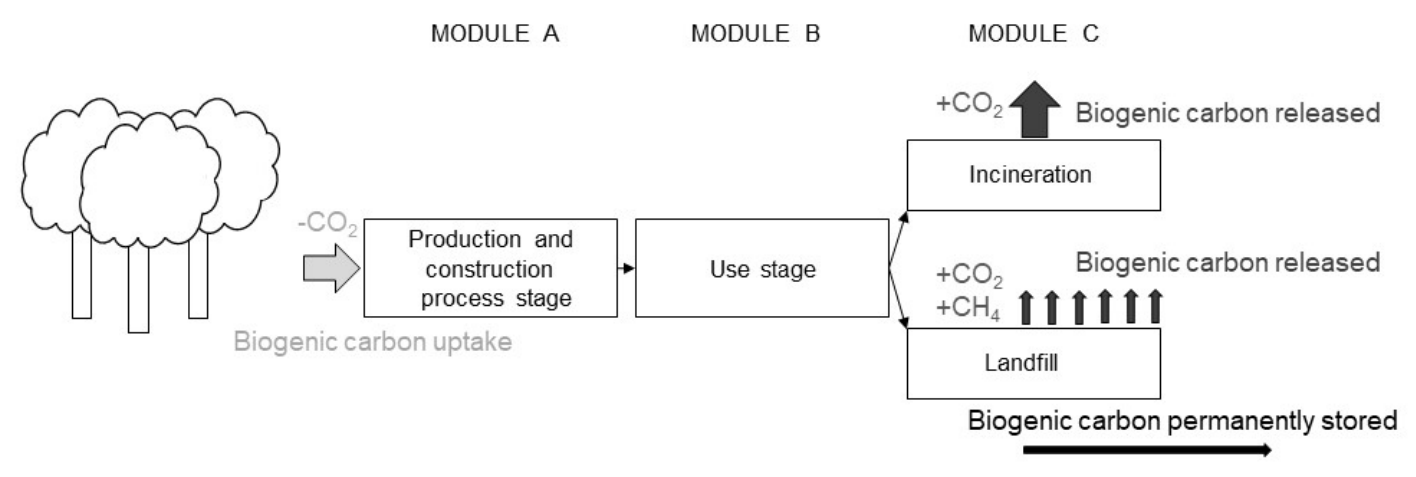

Biogenic carbon temporarily stored

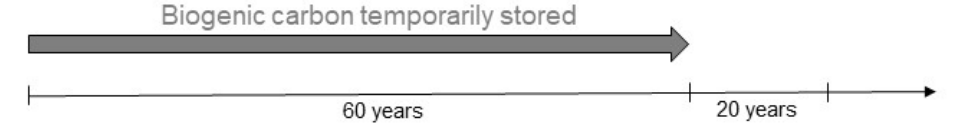

294 Figure 4 Schematic representation of accounted biogenic carbon.

295 Table 4 Summary of the EOL scenarios and related carbon conversion factors for landfill

\begin{tabular}{lcccc}
\hline Material & \multicolumn{3}{c}{ EOL scenarios } & Carbon conversion \\
\hline Structural hardwood & Incineration & Landfill & Recycling & Landfill \\
Structural softwood & $95 \%$ & $5 \%$ & $0 \%$ & $7.8 \%$ \\
Laminated veneer lumber & $95 \%$ & $5 \%$ & $0 \%$ & $1.8 \%$ \\
Oriented strand board & $75 \%$ & $5 \%$ & $20 \%$ & $1.4 \%$ \\
Wood fiber board & $75 \%$ & $5 \%$ & $20 \%$ & $19.9 \%$ \\
Wood wool & $75 \%$ & $5 \%$ & $20 \%$ & $1.3 \%$ \\
Cellulose & $100 \%$ & $0 \%$ & $0 \%$ & $/$ \\
PIR, PUR, XPS & $100 \%$ & $0 \%$ & $0 \%$ & $/$ \\
Mineral wool & $100 \%$ & $0 \%$ & $0 \%$ & $/$ \\
Gypsum plasterboard & $0 \%$ & $100 \%$ & $0 \%$ & $/$ \\
EPDM & $0 \%$ & $95 \%$ & $5 \%$ & $/$ \\
\end{tabular}

297 3. Results and discussion

\section{$298 \quad 3.1 \quad$ Walls}

\section{$299 \quad$ 3.1.1 Baseline scenario}

300 The life-cycle environmental cost of the nine timber frame variants (see Table 1) is shown in Figure 5. The

301 walls composed of wooden studs had a similar material impact than their equivalent walls composed of I-

302 joists. I-joists had a lower production (11\%) and EOL (5 \%) impact than solid studs. The environmental 

waste disposal. Despite a $12 \%$ lower life cycle impact of the timber frame composed of I-joists, the material life-cycle cost of the entire wall was similar for both cases due to the higher amount of insulation material in the frame composed of I-joists. Compared to solid studs of 14.5 (XPS), 19.5 and $24.5 \mathrm{~cm}$, the environmental impact due to operational energy use was $19 \%, 22 \%$, respectively and $20 \%$ lower for their equivalent I-joist, due to the higher insulation fraction with a better thermal resistance than wood. This resulted in a total environmental impact reduction of $0 \%, 7 \%$ and $6 \%$, respectively. Using solid studs or I-joists of 24.5 and 24 $\mathrm{cm}$, respectively instead of 19.5 and $20 \mathrm{~cm}$ did not lead to an important reduction in environmental impact.

311 The environmental life-cycle impact of the wall with the I-joists of $24 \mathrm{~cm}$ is only slightly (1\%) lower than that 312 of the wall composed of I-joists of $20 \mathrm{~cm}$. Studs combined with an extra insulation layer in XPS had a $6.5 \%$

313 lower environmental impact compared to an extra insulation layer in wood fiber. A wall consisting of I-joists 314 of $24 \mathrm{~cm}$ had an equal material and energy impact as the wall consisting of I-joist combined with an XPS 315 layer. The latter solution resulted in a thinner wall and had the additional advantage that the impact of 316 thermally weaker points of the wall, namely the wooden studs or I-joists, were reduced. When taking the 317 influence of biogenic carbon into account, the environmental impact was reduced by $15 \%$ to $21 \%$ but overall, 318 the same trends were observed. There were no clear changes in the environmentally preferred option.

319 However, the environmental impact of an I-joist with an insulating wood fiber board (I16 (WfB)) decreased by $32021 \%$ and had an equal environmental impact as I16 (XPS) and I24, of which the latter two also had the lowest environmental impact when not considering biogenic carbon. 


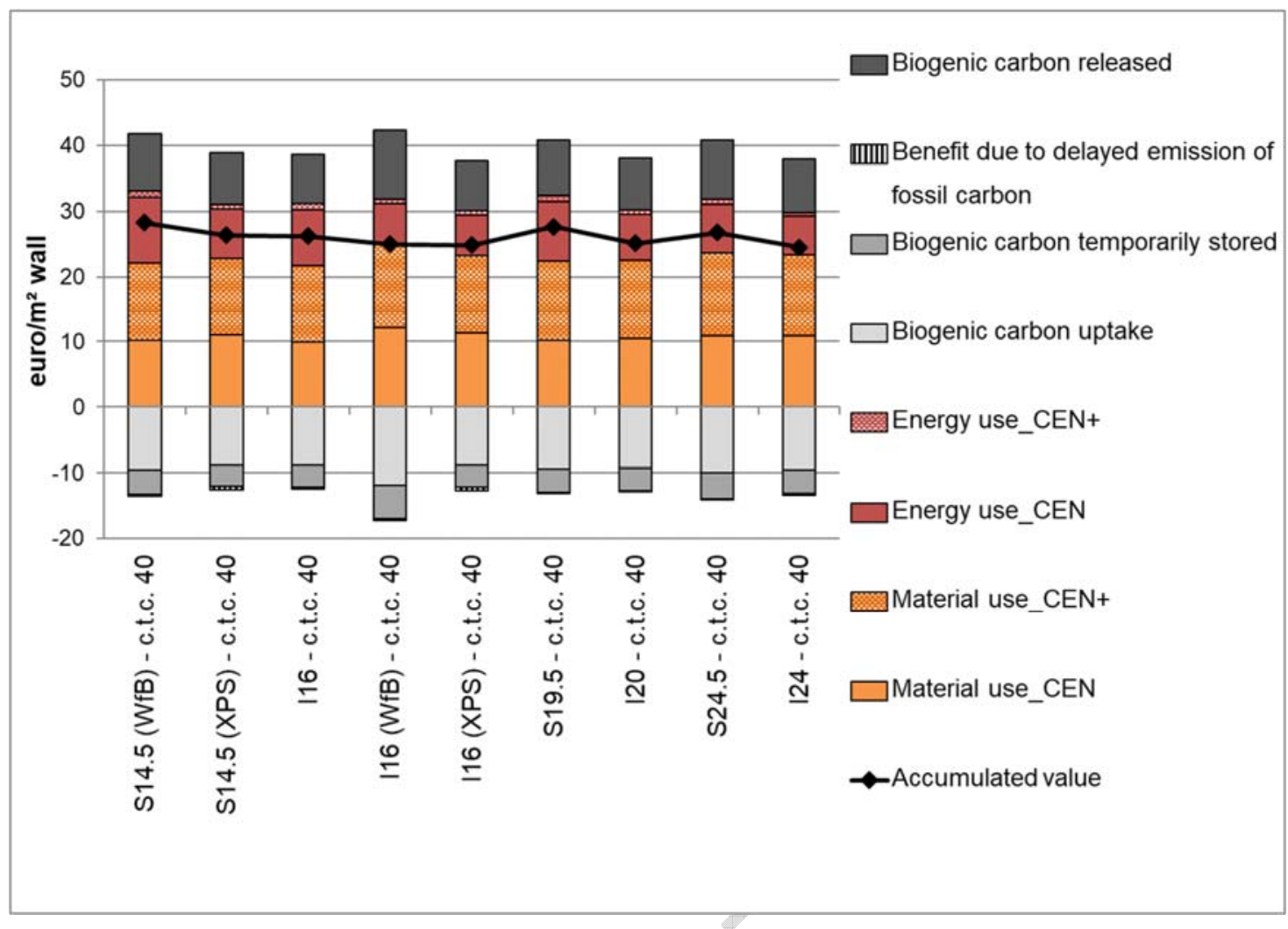

323 Figure 5 Environmental Life-Cycle Cost, subdivided in material and energy impact, expressed in euro/ $\mathrm{m}^{2}$

324 wall.

\section{$325 \quad$ 3.1.2 Variation of center-to-center distance of studs and windows}

326 Besides the stud type and dimensions, the center-to-center (c.t.c) distance between the studs determines the 327 material and energy impact and hence the total environmental impact of the wall. Therefore, the c.t.c. distance 328 of $40 \mathrm{~cm}$ in the nine walls in the previous step, had been changed to $60 \mathrm{~cm}$. Furthermore, the impact of taking 329 windows into account was analyzed as well. According to the regulations in the Brussels Capital Region, $20 \%$ of the floor surface should be glazed in the walls. This parameter was considered in this study by including two windows per façade, which together represented an area of one fourth of $20 \%$ (four façades in total) of the floor area of an average Flemish detached building. The change in material ratios (i.e. wood and insulation) was considered in the analysis. The impact of the window frames and glazing was not taken into account as the focus is on the environmental impact reduction of the timber frame construction. An overview of the material ratios as well as the R-value is provided in Table 5. The environmental impact of sixteen possible combinations by changing the before mentioned material ratio's is shown in Figure 6. Four sets of results are shown. In every set the same wall composition is shown for: (1) a blank wall with a c.t.c distance of $40 \mathrm{~cm}$ (identical to the results in Figure 5), (2) a wall with a c.t.c distance of $40 \mathrm{~cm}$ with window openings 
$34060 \mathrm{~cm}$ with window openings representing an area of $20 \%$. Adjusting the c.t.c distance to $60 \mathrm{~cm}$ led to an

341 environmental impact reduction of $2.9 \%$ on average for solid studs and $1.6 \%$ for I-joists and $2.5 \%$ and 1.8

$342 \%$, respectively when the window openings were taken into account.

343 Table 5 Summary of the assumptions regarding center-to-center distances with and without window openings.

\begin{tabular}{|c|c|c|c|}
\hline Name & $\begin{array}{c}\text { R-value } \\
\left(W / \mathbf{m}^{2} K / W\right)\end{array}$ & Wood fraction & Insulation fraction \\
\hline S14.5 (WfB) - c.t.c 40 & 4.55 & $16.48 \%$ & $83.52 \%$ \\
\hline $\mathrm{S} 14.5(\mathrm{WfB})-$ c.t.c $40+$ windows & 4.05 & $23.98 \%$ & $76.02 \%$ \\
\hline S14.5 (WfB $)-$ c.t.c 60 & 4.69 & $12.96 \%$ & $87.04 \%$ \\
\hline S14.5 (WfB $)$ - c.t.c $60+$ windows & 4.23 & $20.50 \%$ & $79.50 \%$ \\
\hline I16 (WfB $)-$ c.t.c 40 & 7.28 & $11.98 \%$ & $88.02 \%$ \\
\hline $\mathrm{I} 16(\mathrm{WfB})-$ c.t.c $40+$ windows & 7.14 & $15.84 \%$ & $84.16 \%$ \\
\hline I16 (WfB $)-$ c.t.c 60 & 7.43 & $9.86 \%$ & $90.14 \%$ \\
\hline I16 (WfB $)-$ c.t.c $60+$ windows & 7.30 & $13.47 \%$ & $86.53 \%$ \\
\hline S24.5 - c.t.c 40 & 5.95 & $16.48 \%$ & $83.52 \%$ \\
\hline S24.5 - c.t.c $40+$ windows & 5.28 & $23.98 \%$ & $76.02 \%$ \\
\hline S24.5 - c.t.c 60 & 6.34 & $12.96 \%$ & $87.04 \%$ \\
\hline S 24.5 - c.t.c $60+$ windows & 5.57 & $20.50 \%$ & $79.50 \%$ \\
\hline $\mathrm{I} 24-$ c.t.c 40 & 7.48 & $10.56 \%$ & $89.44 \%$ \\
\hline I $24-$ c.t.c $40+$ windows & 7.29 & $14.05 \%$ & $85.95 \%$ \\
\hline $\mathrm{I} 24-$ c.t.c 60 & 7.66 & $8.88 \%$ & $91.12 \%$ \\
\hline I $24-$ c.t.c $60+$ windows & 7.48 & $12.18 \%$ & $87.82 \%$ \\
\hline
\end{tabular}

* Note: $\mathrm{S}=$ studs and $\mathrm{I}=\mathrm{I}$-joists, the numbers after the letters refer to the thickness. 


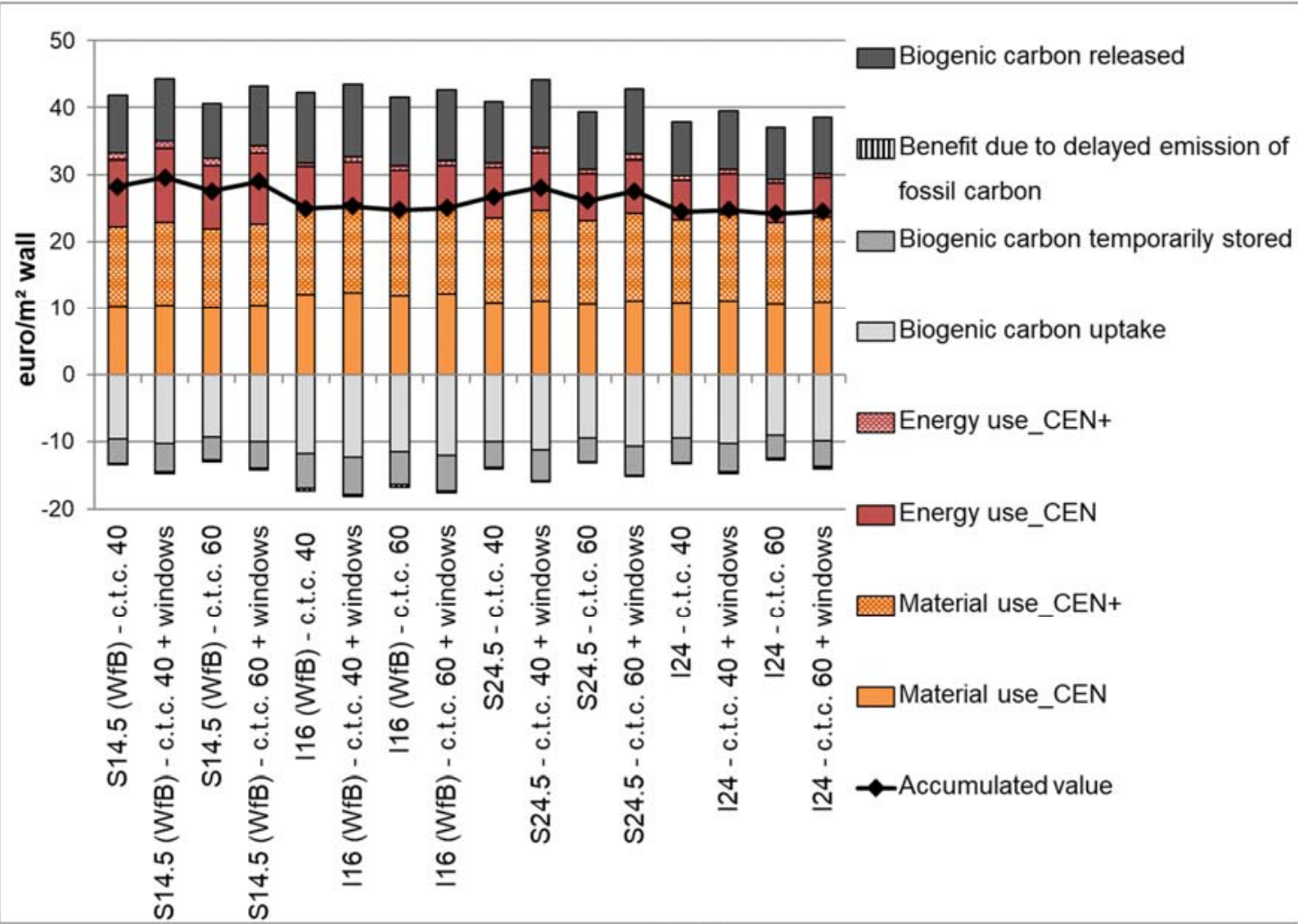

347 Figure 6 Environmental Life-Cycle Cost, subdivided in material and energy impact, expressed in euro/ $\mathrm{m}^{2}$ wall.

\subsubsection{Variation in insulation material}

350 The impact of changing insulation materials is shown in Figure 7 for a wall consisting of I-joists of $16 \mathrm{~cm}$ and a c.t.c distance of $60 \mathrm{~cm}$, filled with glass wool and an extra insulating wood fiber board. The difference

352 between the $1^{\text {st }}$ and $2^{\text {nd }}$ variant are different in that the bituminous wood fiber board of $18 \mathrm{~mm}$ was replaced by an insulating wood fiber board of $35 \mathrm{~mm}$ combined with a water-tight damp open foil in the $2^{\text {nd }}$ variant.

354 Furthermore, the insulating wood fiber board of $80 \mathrm{~mm}$ on the outside was removed and the originally unfilled technical cavity was replaced by an insulated technical cavity consisting of a wood fiber board of $50 \mathrm{~mm}$. These changes resulted in a $23 \%$ lower material impact, but in a $6 \%$ higher energy impact. The total environmental impact was reduced by $17 \%$. The $2^{\text {nd }}, 3^{\text {rd }}, 4^{\text {th }}$ and $5^{\text {th }}$ variant analyzed only differed in the insulation materials used in between the I-joist: glass wool, stone wool, cellulose and wood wool, respectively. With cellulose $\left(\mathrm{R}_{\text {wall }}=6.16 \mathrm{~m}^{2} \mathrm{~K} / \mathrm{W}\right)$ or wood wool $\left(\mathrm{R}_{\text {wall }}=6.08 \mathrm{~m}^{2} \mathrm{~K} / \mathrm{W}\right)$, the total environmental impact can be further reduced by $2 \%$ and $4 \%$, respectively. If biogenic carbon was taken into account, the total impact for wood wool was reduced by $8 \%$ compared to glass wool. 


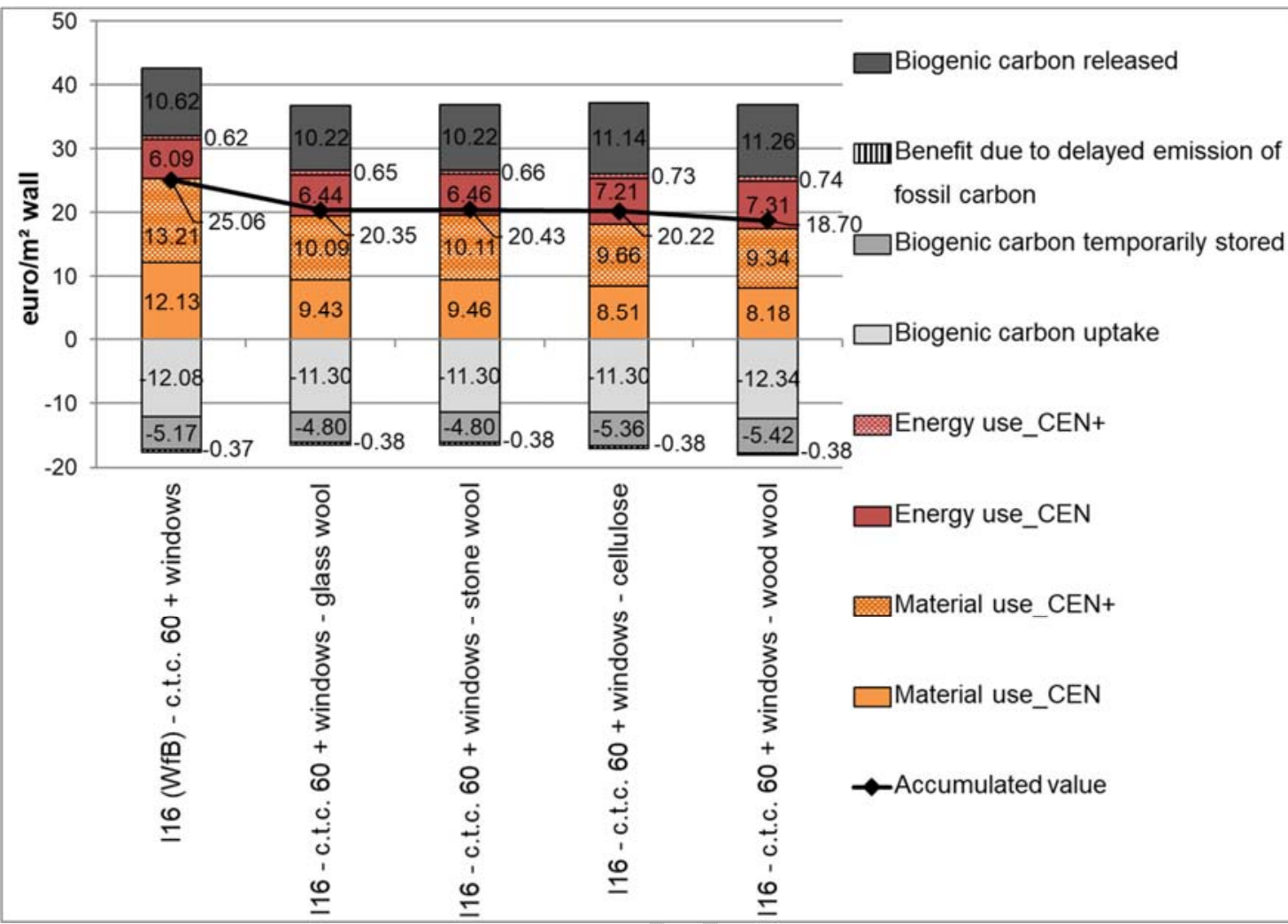

364 Figure 7 Environmental Life-Cycle Cost, subdivided in material and energy impact, expressed in euro/ $\mathrm{m}^{2}$ wall.

\section{$366 \quad$ 3.1.4 Variation in insulation level (R-value)}

367 To help designers select the most environmentally friendly combination of basic constructions (I16, I20, I24) and additional layers of XPS and WfB, the different components of the environmental cost and their sum are represented in function of the R-value in Figure 8. The standard scenario, where biogenic $\mathrm{CO}_{2}$ is excluded, corresponds to "indefinite perspective" whereas the scenario in which biogenic $\mathrm{CO}_{2}$ is included corresponds to "short-term perspective" taking delayed emissions into account. The wall is composed as described in Figure 2. However, based on case results, the timber frame was filled with wood wool instead of glass wool and the bituminized wood fiber board was replaced by a wood fiber board of $18 \mathrm{~mm}$ combined with a water-tight damp open foil. The thickness of the extra insulation layer varied from 0 to $15 \mathrm{~cm}$ in steps of one $\mathrm{cm}$. A

375 thicker basic construction led to a higher R-value but also to slightly higher material cost. Per additional $\mathrm{cm}$ of 376 XPS or WfB the R-value will increase, depending on the $\lambda$-value, but each additional $\mathrm{cm}$ requires an additional 377 environmental material cost. Those two lines, representing the extra insulation layer material cost, show a different slope and start from a different R-value for the three basic constructions (I16, I20, I24). The starting 
379 points of the environmental material cost increase with increased R-value. The slope of the line connecting

380 those starting points is less steep than the lines expressing the material cost of an extra thermal resistance.

381 Hence, it is more environmentally friendly to select a thicker I-joist than to increase the thickness of the

382 additional layer. In case biogenic $\mathrm{CO}_{2}$ is excluded from the calculations, as shown on the left-hand graph in Figure 8, the slope of the material cost for XPS is less steep than for WfB and hence the former is more environmentally friendly. The total environmental cost is obtained by adding up the material cost and the energy cost for heating. The energy cost is represented by a downward-sloping hyperbolic function. The most optimal solution in these calculations is an I-joist of $24 \mathrm{~cm}$ combined with an extra insulation layer of $4 \mathrm{~cm}$ XPS $\left(\mathrm{R}_{\mathrm{wall}}=6.93 \mathrm{~m}^{2} \mathrm{~K} / \mathrm{W}\right)$. If biogenic $\mathrm{CO}_{2}$ is included, as shown on the right-hand graph in Figure 8, the slope of the material cost for XPS is steeper than for WfB and hence the latter is more environmentally friendly per extra thermal resistance. The most optimal solution in these calculations is an I-joist of $24 \mathrm{~cm}$ combined with an extra insulation layer of $12 \mathrm{~cm} \mathrm{WfB}$.

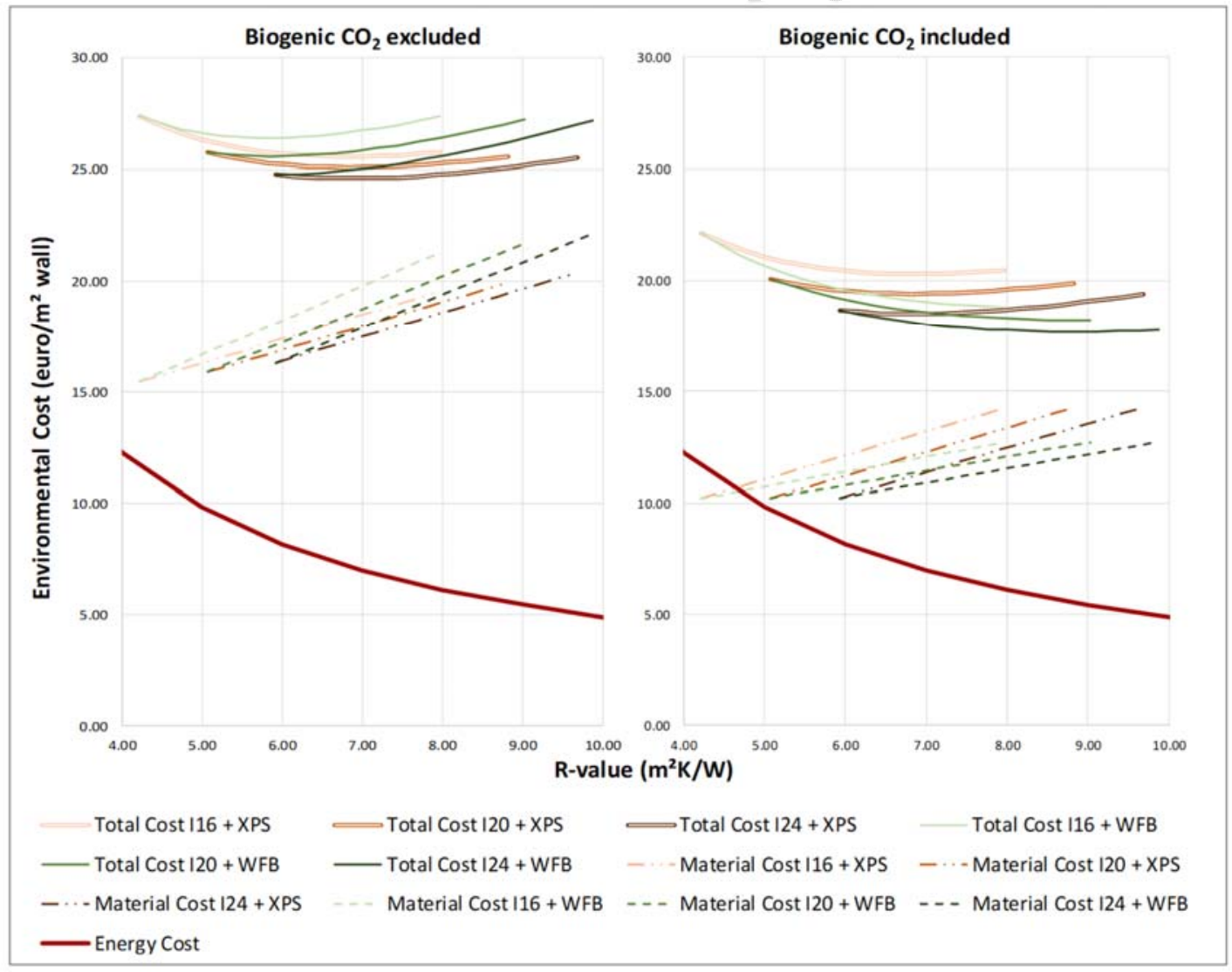


Figure 8 Environmental Life-Cycle Cost of a timber frame wall composed of I-joists, excluding (left) and including (right) a credit for biogenic carbon. The results are expressed per R-value and subdivided in energy, material and total cost.

The total cost will decrease until the reduction of the energy cost is insufficient to compensate for the higher environmental material cost. The reduction of energy cost depends on various factors: winter conditions for a given location, heating system efficiency, internal and solar heat gains and expected service life. The impact on the results of changing these factors is shown in Figure 9, assuming a building service life of 30 years, 900 equivalent degree days and a heating system efficiency of $90 \%$. The conclusions are slightly different but are similar if biogenic carbon is included or not. The most optimal solution is in both cases an I-joist of $24 \mathrm{~cm}$.
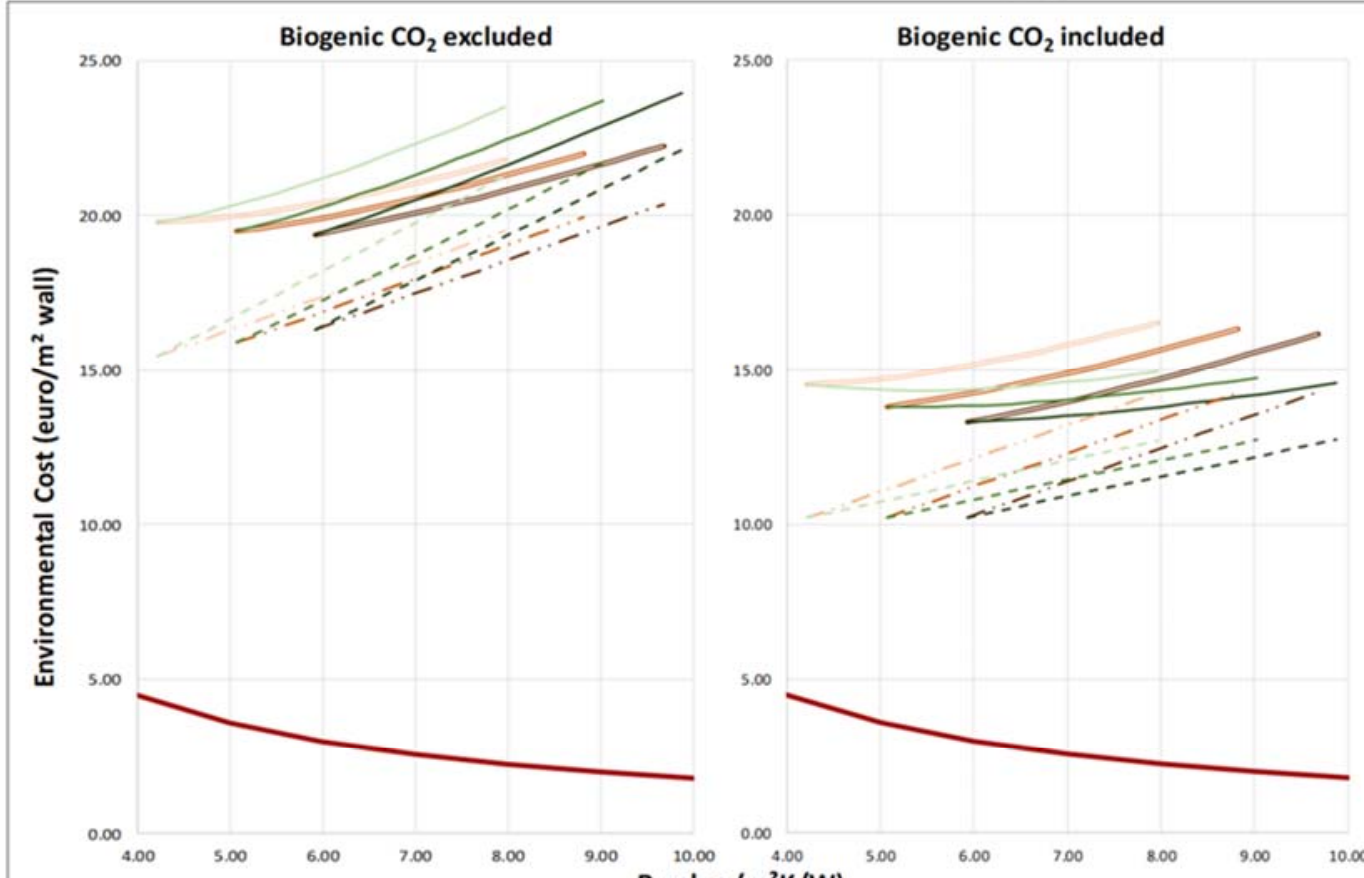

10.00

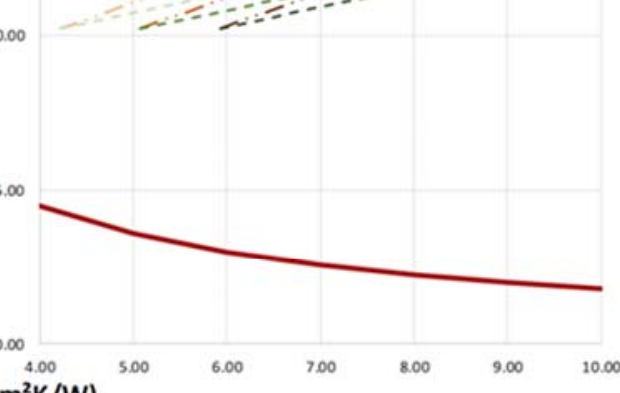

R-value $\left(m^{2} K / W\right)$

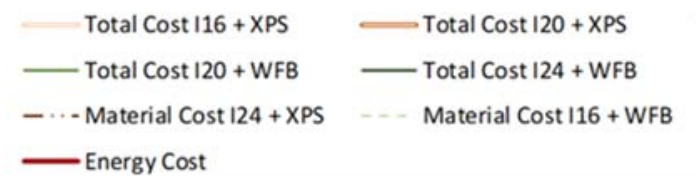

$\longrightarrow$ Total Cost $124+$ XPS

Total Cost $116+$ WFB

- Material Cost I16 + XPS _- Material Cost $120+$ XPS

- Energy Cost

Figure 9 Environmental Life Cycle Cost of a timber frame wall composed of I-joists, excluding (left) and material and total cost.

\subsection{Roofs}


The life-cycle environmental cost of the four roof variants is shown in Figure 10. The difference in total environmental impact between the first three variants is only slight. However, the third option had a $21 \%$

411 higher material impact compared to the first one. The composition with cellulose had a slightly higher material impact (4\%) than the first solution with PIR, but a lower impact regarding operational energy use, resulting in

413 a $14 \%$ lower total environmental impact. Moreover, the last option resulted in a thinner roof structure. Taking biogenic carbon into account led to an environmental impact reduction of $15 \%$ on average. However, the environmentally preferred option did not change by taking biogenic carbon into account.

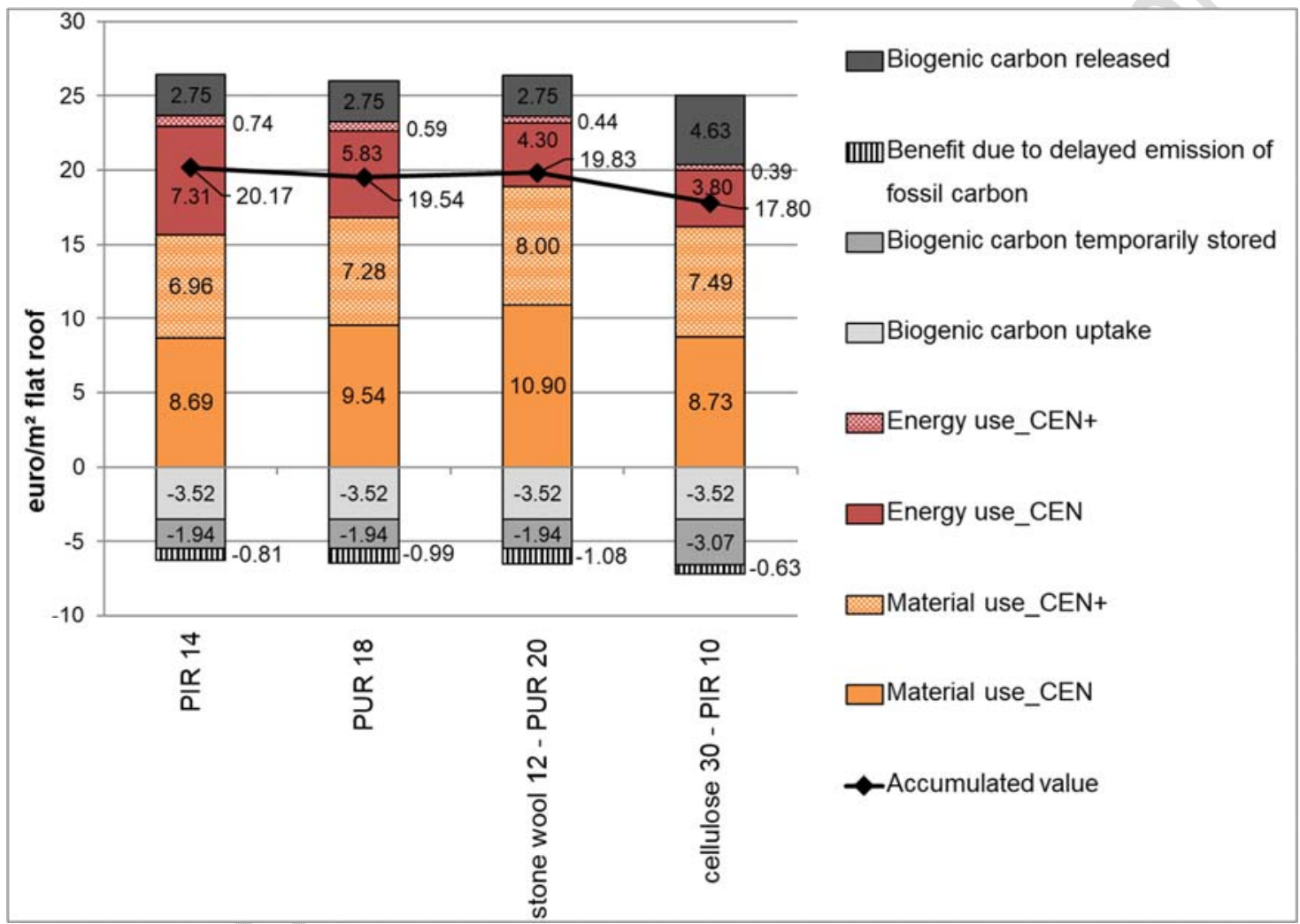

417 Figure 10 Environmental Life-Cycle Cost, subdivided in material energy impact, expressed in euro $/ \mathrm{m}^{2}$ roof.

\section{$418 \quad 3.3 \quad$ Discussion}

419 The results of this study confirmed the importance of considering the material impact in case of well-insulated

420 newly-built constructions. For the walls analyzed, the ratio material impact to total impact ranged from $65 \%$

421 to $80 \%$. The impact of biogenic carbon was assessed based on a static approach considering a credit for the

422 biogenic carbon that is stored during the service life of the building. The results showed a considerable

423 reduction in the total environmental impact although in most cases the preferred choice from an environmental

424 point of view did not change. When comparing timber frame walls with alternative construction types, the

425 inclusion of biogenic carbon credits might influence the preferred solution. This was clearly shown in the 

the importance of EOL scenarios considered in LCA is acknowledged, the EOL assumptions in this research are based on the current waste treatment in Belgium. Given considerable uncertainty about future EOL treatment processes, their influence is hard to predict and was not further investigated in this study. The results were calculated based on the MMG central monetization values for Western-Europe. As monetary valuation adds another level of uncertainty to the results, the effect of the monetization values uncertainty on the results had been checked by applying as well the low as high monetization values (Figure S1-S8 and

Table S18). The characterized results are moreover included in the supplementary material for reasons of transparency (Table S12-S17). Although the environmental cost varies strongly between the different scenarios considered, the overall trend in the results remains similar. Global warming, particulate matter, land occupation-biodiversity, human toxicity cancer and non-cancer effects and eutrophication are the impact categories contributing most to the aggregated results. Replacing solid studs by I-joists results in a slightly higher impact on global warming and eutrophication $(<1 \%)$, a remarkable higher impact for human toxicity $(+20 \%)$, but a lower impact for particulate matter $(-16 \%)$ and land occupation-biodiversity (-9\%). The percentages between the brackets illustrate the differences in the case of a solid stud of $24.5 \mathrm{~cm}$ and an I-joist of $24 \mathrm{~cm}$. The specific percentages differ for other stud thicknesses but the overall trend remains similar. Changing the extra insulation layer from woodfibre to XPS (I16 (WfB) to I16 (XPS)) leads to a decrease in all impact categories. Replacing a thinner stud with an extra insulation layer (I16 (XPS)) by a thicker stud (I24) results in a decrease for global warming (18\%) and particulate matter (2\%) but a slight increase for eutrophication, human toxicity non cancer effects and land occupation-biodiversity $(<3 \%)$ and an increase of $8 \%$ of human toxicity cancer effects. Changing the glass wool insulation by wood wool insulation results in a decrease of all impact categories. Furthermore, the study identified the lack of data regarding wood treatment processes in generic databases such as Ecoinvent and the Belgian LCA database for buildings. In the latter, only untreated wood and wood treated with chromium (limited to the EOL processes) are included. However, chromium-preserved wood is no

451 longer used in Belgium. Instead, for structural wood, an organic-based wood preservative is typically used.

452 This preservative was therefore modelled in detail based on available documentation of the conventional wood 453 treatment processes and adapted generic data. The analysis showed that the environmental cost caused by 454 chromium-based treatment is $90 \%$ higher than when an organic solvent based preservative is used. Compared to untreated wood, chromium-preserved wood has a $105 \%$ higher environmental cost while wood treated with 
an organic solvent based preservative only has a $8 \%$ higher environmental cost. Based on this result, it is recommended to improve inventory data regarding wood preservative processes in generic databases.

\section{Conclusions}

459 This paper analyzed the potential environmental impact reduction of timber frame constructions for rooftop 460 extensions, focusing both on external walls and flat roofs. Various parameters were assessed based on a life461 cycle assessment. A timber frame wall was assessed over a service life of 60 years, considering material use 462 and energy for compensating transmission losses. The results show a limited environmental impact reduction 463 of up to $7 \%$ for I-joist use instead of solid studs. Increasing the center-to-center distance from $40 \mathrm{~cm}$ to $60 \mathrm{~cm}$ 464 offered a reduction in environmental impact of between 1.5 and $3 \%$. Changing the composition of the walls in 465 terms of materials can lead to a total life-cycle environmental reduction of $17 \%$, due to a $23 \%$ lower material impact and a $6 \%$ higher operational energy use impact. Using wood wool insulation, replacing the

467 bituminized wood fiber board by a wood fiber board combined with a water-tight damp open foil and using thicker studs instead of thinner studs with an extra insulation layer results in a reduction of the environmental impact. To further reduce the transmission losses at the I-joists an extra insulation layer could be added.

470 Whether or not including biogenic carbon can lead to significant differences in the environmentally preferred

471 choice of this extra insulation layer. If biogenic carbon is included, an extra wood fibre board of $12 \mathrm{~cm}$ resulted

472 in the lowest environmental impact for the Belgian climate and a service life of 60 years. If biogenic carbon is

473 not included, an extra insulation layer of $4 \mathrm{~cm}$ XPS was more environmentally favorable. However, for a

474 shorter life span and/or milder climate, an extra insulation layer does not always result in a lower

475 environmental impact. Moreover, four different insulation scenarios for a roof composed of I-joists were

476 analyzed. In these roof compositions, a total life-cycle environmental reduction of $14 \%$ can be achieved. The

477 influence of taking biogenic carbon into account was analyzed and showed a reduction of the total life-cycle

478 environmental impact of up to $35 \%$.

\section{5. Abbreviation list}

\begin{tabular}{ll}
\hline c.t.c & Center-to-center \\
\hline EOL & End-of-life \\
\hline EPB & Energy Performance of Buildings \\
\hline EPDM & Ethylene propylene diene monomer \\
\hline GHG & Greenhouse gas \\
\hline$\lambda$-value & Thermal conductivity value \\
\hline
\end{tabular}




\begin{tabular}{ll}
\hline LCA & Life-Cycle Assessment \\
\hline LCI & Life-Cycle Inventory \\
\hline LVL & Laminated veneer lumber \\
\hline OSB & Oriented strand board \\
\hline PIR & Polyisocyanurate \\
\hline PUR & Polyurethane \\
\hline R-value & Thermal resistance value \\
\hline U-value & Thermal transmittance value \\
\hline WfB & Wood fiber board \\
\hline XPS & Extruded polystyrene \\
\hline
\end{tabular}

6. Acknowledgements

This work was supported by Flanders Innovation \& Entrepreneurship (VLAIO), former Agency for Innovation

by Science and Technology (IWT).

\section{References}

Aalde, H., Gonzalez, P., Gytarsky, M., Krug, T., Kurz, W., Ogle, S., Raison, J., Schoene, D., Ravindranath, N., Elhassan, N., Heath, L., Higuchi, N., Kainja, S., Matsumoto, M., Sanchez, M., Somogyi, Z., 2006. IPCC Guidelines for National Greenhouse Gas Inventories, Volume 4, Chapter 4 Forest Land.

Achenbach, H., Wenker, J.L., Rüter, S., 2018. Life cycle assessment of product- and construction stage of prefabricated timber houses: a sector representative approach for Germany according to EN 15804, EN 15978 and EN 16485. Eur. J. Wood Wood Prod. 76, 711-729. https://doi.org/10.1007/s00107017-1236-1

Allacker, K., 2010. Sustainable building, The development of an evaluation method ( $\mathrm{PhD}$ dissertation). KU Leuven, Heverlee.

Allacker, K., Debacker, W., Delem, L., De Nocker, L., De Troyer, F., Janssen, A., Peeters, K., Servaes, R., Spirinckx, C., Van Dessel, J., 2013. Environmental profile of building elements. OVAM, Mechelen.

Artola, I., Rademaekers, K., Williams, R., Yearwood, J., 2016. Boosting Building Renovation:What potential and value for Europe? (No. IP/A/ITRE/2013-046; PE 587.326). European Union - Policy Department A: Economic and Scientific Policy, Brussels.

Asadi, E., da Silva, M.G., Antunes, C.H., Dias, L., 2012. Multi-objective optimization for building retrofit strategies: A model and an application. Energy Build. 44, 81-87. https://doi.org/10.1016/j.enbuild.2011.10.016

Brandão, M., Levasseur, A., Kirschbaum, M.U.F., Weidema, B.P., Cowie, A.L., Jørgensen, S.V., Hauschild, M.Z., Pennington, D.W., Chomkhamsri, K., 2013. Key issues and options in accounting for carbon sequestration and temporary storage in life cycle assessment and carbon footprinting. Int. J. Life Cycle Assess., 18, 230-240, 10.1007/s11367-012-0451-6.

Brown, N.W.O., Malmqvist, T., Bai, W., Molinari, M., 2013. Sustainability assessment of renovation packages for increased energy efficiency for multi-family buildings in Sweden. Build. Environ. 61, 140-148. https://doi.org/10.1016/j.buildenv.2012.11.019

CEN (Ed.), 2013. EN 15804+A1 Sustainability of construction works - Environmental product declaration Core rules for the product category of construction products.

CEN (Ed.), 2011. EN 15978 Sustainability assessment of construction works - assessment of environmental performance of buildings - calculation method.

De Nocker, L., Debacker, W., 2015. Annex: Update monetisation of the MMG method (2014). OVAM, Mechelen.

Diensten voor de programmatie van het wetenschapsbeleid, 1984. Ontwerp en thermische uitrusting van gebouwen - deel 2 (translated title: Design and technical equipment of buildings - part 2). Brussels.

Dobbels, F., 2016. Vraag ivm behandeling structureel hout.

Ecoinvent, 2014. Ecoinvent [WWW Document]. URL http://www.ecoinvent.ch/

Eurostat, 2018a. Population Density - Eurostat [WWW Document]. URL http://ec.europa.eu/eurostat/web/products-datasets/-/tps00001 (accessed 4.13.17). 
Eurostat, 2018b. Population on 1 January - Eurostat [WWW Document]. URL http://ec.europa.eu/eurostat/web/products-datasets/-/tps00001 (accessed 4.13.17).

Eurostat, 2018c. Built-up areas - Eurostat [WWW Document]. URL http://ec.europa.eu/eurostat/web/productsdatasets/-/t2020 rd110 (accessed 4.13.17).

Famuyibo, A.A., Duffy, A., Strachan, P., 2013. Achieving a holistic view of the life cycle performance of existing dwellings. Build. Environ. 70, 90-101. https://doi.org/10.1016/j.buildenv.2013.08.016

Federale overheidsdienst economie, K.M.O., middenstand en energie, 2009. STS 04 Hout en plaatmaterialen op basis van hout STS 04.3 Behandelingen van hout. Federale overheidsdienst economie, K.M.O., middenstand en energie, Brussel.

Garcia, R., Freire, F., 2014. Carbon footprint of particleboard: a comparison between ISO/TS 14067, GHG Protocol, PAS 2050 and Climate Declaration. J. Clean. Prod. 66, 199-209. https://doi.org/10.1016/j.jclepro.2013.11.073

General Secretariat of the European Council, 2014. European Council (23 and 24 October 2014) - Conclusions (No. EUCO 169/14). European Council, Brussels.

Häfliger, I.-F., John, V., Passer, A., Lasvaux, S., Hoxha, E., Saade, M.R.M., Habert, G., 2017. Buildings environmental impacts' sensitivity related to LCA modelling choices of construction materials. J. Clean. Prod. 156, 805-816. https://doi.org/10.1016/j.jclepro.2017.04.052

Hafner, A., Schäfer, S., 2017. Comparative LCA study of different timber and mineral buildings and calculation method for substitution factors on building level. J. Clean. Prod. 167, 630-642. https://doi.org/10.1016/j.jclepro.2017.08.203

Ibn-Mohammed, T., Greenough, R., Taylor, S., Ozawa-Meida, L., Acquaye, A., 2013. Operational vs. embodied emissions in buildings-A review of current trends. Energy Build. 66, 232-245. https://doi.org/10.1016/j.enbuild.2013.07.026

IES, 2010. International Reference Life Cycle Data System (ILCD) Handbook - General guide for Life Cycle Assessment - Detailed guidance.

Ingrao, C., Scrucca, F., Tricase, C., Asdrubali, F., 2016. A comparative Life Cycle Assessment of external wall-compositions for cleaner construction solutions in buildings. J. Clean. Prod. 124, 283-298. https://doi.org/10.1016/j.jclepro.2016.02.112

Kovacic, I., Reisinger, J., Honic, M., 2018. Life Cycle Assessment of embodied and operational energy for a passive housing block in Austria. Renew. Sustain. Energy Rev. 82, 1774-1786. https://doi.org/10.1016/j.rser.2017.07.058

Levasseur, A., Lesage, P., Margni, M., Samson, R., 2013. Biogenic Carbon and Temporary Storage Addressed with Dynamic Life Cycle Assessment: Biogenic Carbon and Temporary Storage in LCA. J. Ind. Ecol. 17, 117-128. https://doi.org/10.1111/j.1530-9290.2012.00503.x

Ma, Z., Cooper, P., Daly, D., Ledo, L., 2012. Existing building retrofits: Methodology and state-of-the-art. Energy Build. 55, 889-902. https://doi.org/10.1016/j.enbuild.2012.08.018

Maxineasa, S.G., Entuc, I.-S., Taranu, N., Florenta, I., Secu, A., 2018. Environmental performances of different timber structures for pitched roofs. J. Clean. Prod. 175, 164-175. https://doi.org/10.1016/j.jclepro.2017.12.047

Micales, J.A., Skog, K.E., 1997. The decomposition of forest products in landfills. Int. Biodeterior. Biodegrad. 39, 145-158. https://doi.org/10.1016/S0964-8305(97)83389-6

Moreno, A.I., Font, R., Conesa, J.A., 2017. Combustion of furniture wood waste and solid wood: Kinetic study and evolution of pollutants. Fuel 192, 169-177. https://doi.org/10.1016/j.fuel.2016.12.022

NBN EN 335, 2013. Durability of wood and wood-based products - Use classes: definitions, application to solid wood and wood-based products. Bureau voor Normalisatie, Brussel.

NBN EN 16449, 2014. Wood and wood-based products - Calculation of the biogenic carbon content of wood and conversion to carbon dioxide. Bureau voor Normalisatie, Brussel.

Risholm-Sundman, M., Vestin, E., 2005. Emissions during combustion of particleboard and glued veneer. Holz Als Roh- Werkst. 63, 179-185. https://doi.org/10.1007/s00107-004-0549-z

Ryckewaert, M., De Decker, P., Winters, S., Vandekerckhove, B., Vastmans, F., Elsinga, M., Heylen, K., 2011. Een woonmodel in transitie. Toekomstverkenning van het Vlaamse wonen. Garant, Antwerpen/Apeldoorn.

Salthammer, T., Klipp, H., Peek, R.-D., Marutzky, R., 1995. Formation of Polychlorinated Dibenzo-P-Dioxins (PCDD) and Polychlorinated Dibenzofurans (PCDF) during the combustion of impregnated wood. Chemosphere Vol.30, 2051-2060.

Silva, P.C.P., Almeida, M., Bragança, L., Mesquita, V., 2013. Development of prefabricated retrofit module towards nearly zero energy buildings. Energy Build. 56, 115-125. https://doi.org/10.1016/j.enbuild.2012.09.034

Stephan, A., Crawford, R.H., de Myttenaere, K., 2013. A comprehensive assessment of the life cycle energy demand of passive houses. Appl. Energy 112, 23-34. https://doi.org/10.1016/j.apenergy.2013.05.076 
Tame, N.W., Dlugogorski, B.Z., Kennedy, E.M., 2007. Formation of Polychlorinated Dibenzo- $p$-Dioxins and Polychlorinated Dibenzofurans (PCDD/F) in Fires of Arsenic-Free Treated Wood: Role of Organic Preservatives. Environ. Sci. Technol. 41, 6425-6432. https://doi.org/10.1021/es0703980

Technische Goedkeuring ATG met Certificatie - Procédés voor de preventieve behandeling van het hout ATG 12/2294 -AXIL MULTI, 2013. . Belgische Unie voor technische goedkeuring in de Bouw, Brussel.

The American Phytopathological Society, 2017. Group Code - CommonAndTradeFungicides [WWW Document]. URL https://www.apsnet.org/edcenter/intropp/topics/Documents/CommonAndTradeFungicides.pdf (accessed 2.28.17).

Vogtländer, J.G., van der Velden, N.M., van der Lugt, P., 2014. Carbon sequestration in LCA, a proposal for a new approach based on the global carbon cycle; cases on wood and on bamboo. Int. J. Life Cycle Assess. 19, 13-23. https://doi.org/10.1007/s11367-013-0629-6

Wang, X., Padgett, J.M., De la Cruz, F.B., Barlaz, M.A., 2011. Wood Biodegradation in Laboratory-Scale Landfills. Environ. Sci. Technol. 45, 6864-6871. https://doi.org/10.1021/es201241g

Wang, X., Padgett, J.M., Powell, J.S., Barlaz, M.A., 2013. Decomposition of forest products buried in landfills. Waste Manag. 33, 2267-2276. https://doi.org/10.1016/j.wasman.2013.07.009

Wijnants, L., Allacker, K., De Troyer, F., 2017. Life cycle assessment of prefabricated timber frame "openrenovation-systems" for rooftop extensions, in: PLEA 2017 Proceedings - Design to Thrive. Presented at the PLEA 2017, Edinburgh, pp. 1612-1619.

Wijnants, L., Allacker, K., De Troyer, F., 2016. Environmental and Financial Life Cycle Assessment of 'Open-renovation-systems': Methodology and Case Study. Energy Procedia 96, 529-539. https://doi.org/10.1016/j.egypro.2016.09.095

Ximenes, F.A., Gardner, W.D., Cowie, A.L., 2008. The decomposition of wood products in landfills in Sydney, Australia. Waste Manag. 28, 2344-2354. https://doi.org/10.1016/j.wasman.2007.11.006

Ximenes, F.A., Grant, T., 2013. Quantifying the greenhouse benefits of the use of wood products in two popular house designs in Sydney, Australia. Int. J. Life Cycle Assess. 18, 891-908. https://doi.org/10.1007/s11367-012-0533-5 